\title{
SPATIAL DIVERSITY OF BIOTECHNOLOGY CENTRES IN GERMANY
}

\author{
SŁAWOMIR DOROCKI \\ Department of Entrepreneurship and Spatial Management, Institute of Geography, Pedagogical University of \\ Cracow, Poland
}

Manuscript received: February 12, 2014

Revised version: March 25, 2014

\begin{abstract}
DoRоскі S., 2014. Spatial diversity of biotechnology centres in Germany. Quaestiones Geographicae 33(2), Bogucki Wydawnictwo Naukowe, Poznań, pp. 151-169, 13 figs. DOI 10.2478/quageo-2014-0023, ISSN 0137-477X.

ABSTRACT: Biotechnology is considered one of the key advanced technology sectors of the future. Its development is conditional on basic research in technologically advanced research institutes and appropriately qualified human resources. The optimum environment stimulating the development of biotechnology is that of production centres having joint industrial and R\&D operations.

The growth of this sector in Germany began later than in the USA or other West European countries. But, thanks to the regional policy pursued by the state stimulating the development of biotechnology clusters, in a period of fifteen years or so, Germany has become the global leader. This paper presents the process of developing biotechnology centres in Germany as well as their spatial distribution, accompanied by their short description.
\end{abstract}

KEY WORDS: biotechnology, Germany, regions, clusters, economic geography

Stawomir Dorocki, Institute of Geography, Pedagogical University of Cracow, Podchorążych 2, 30-084 Kraków, Poland; e-mail: sdorocki@up.krakow.pl

\section{Introduction}

Nowadays, it is assumed that regional economic development is closely related to the development of innovation and technological progress occurring in a region. Innovation and innovation-related economic competitiveness of local administrative units at all levels is predominantly dependent on human capital (Borowiec 2008; Chojnicki, Czyż 2006, 2008; Karlsson, Börje 2008; Borowiec, Dorocki, Jenner 2009; Borowiec, Dorocki 2011). For this reason, this capital is highly trained personnel, including academics (research staff), highly qualified specialists and lower-level staff working in high-tech economic sectors (Kilar 2008). It applies both to their education and skills and their effort to improve their qualifications continuously. The so-called "creative class" is another condition which guarantees the development of innovative sectors. The term also applies to the open attitude the society adopts towards transformations and progress and the place of creative individuals in the society (Stryjakiewicz 2008; Klincewicz 2012). In this context, the culture of social relations is a factor affecting the development of innovation in an area. The attitude of society towards science and progress is particularly important in the case of authorities and functionaries and their actions, both in the financial and legislative aspects. In the context of the above-mentioned terms and conditions for the development of a modern economy, the best conditions for innovation growth are offered by cities, in particular by large 
agglomerations and metropolises (Stryjakiewicz 2009). This is due to economic aspects (such as economic advancement, infrastructure, accessibility of new high-tech solutions and knowledge, the economic structure) as well as social aspects (such as education, business traditions, and the demographic structure). Also, urban centres are migratory goals for a large part of the creative class (Winiarczyk-Raźniak, Raźniak 2012; Gałka, Dorocki 2013).

In addition, an innovative economy is reflected by the type of growing businesses and the R\&D base. In the industrialisation period, which has come to an end, science, and specifically chemistry and physics as well as traditional industry related to these sciences, played the key role in the economic growth. The end of the 20th century brought the dominance of mathematical sciences (including applied mathematics) and IT as well as the electronic industry (the IT revolution) (Kilar 2009). At present, biotechnology is considered one of the most important branches of science. After a period of IT prevalence, biotechnology is now being perceived as the most important and fastest growing high-tech economic sector (Bauer 1995; Kelly 2004). For this reason, biotechnology represents a material factor of social and economic development and of processes involved in creating a knowledge-based economy (Zioło 2006, 2008; Dorocki, Jastrzębski 2012; Pugatch et al. 2012). The importance of biotechnology in developing a knowledge-based economy is related to its core features: innovation, versatile applicability, and generating the progress of other basic sciences. The increasing role of biotechnology is also related to the growth in population number and a possible food crisis in poorly developed regions, the ageing of society occurring in developed countries, and scientific and technological progress. Biotechnology significantly breaks off connections with traditional (hard) business location factors, making its development dependent on soft factors, such as largely human capital and access to new technologies (information, knowledge). This is proved by the fact that in biotech companies the share of employees having the academic title of a doctor is twice or three times higher than in other companies of the R\&D sector (Beuzekom, Arundel 2009). Another important factor stimulating the development of biotechnology is transfer of knowledge and a dense institutional network characteristic of urbanised areas (agglomerations). Spatial concentrations of industry and the biotechnology sector allow strong relations to grow between economic and scientific entities/units and facilitate an exchange of mutually complementary knowledge (Corolleur et al. 2003; Sytch, Bubenzer 2008; Aharonson et al. 2008; Lecocq at al 2010; Béliveau et al. 2011; Domański 2000; Klasik 2009; Chojnicki, Czyż 2008; Markowski 2008; Delerue, Lejeune 2008; Goldberg et al. 2008). The above shows that biotech companies grow mainly in the proximity of world-class universities which provide them with access to highly qualified work force and research infrastructure (Zucker et al. 1989; Stuart, Sorenson 2003). Still, the development involves high investment risk caused by rapid technological changes (Baum, Silverman 2004) and a long period needed to market a product.

Contemporary biotechnology processes are applied in many industrial sectors and successfully compete with traditional methods. Globally, they are broadly applied in such sectors as the chemical industry, pharmaceutical (medical) industry, pulp and paper industry, textile, leather, food processing industries, and the energy sector. The main fields of activity of the biotechnology sector are: production of starter cultures in the food industry, production of GMO, the pharmaceutical sector (production of new drugs, vaccines, diagnostic means), the detergent and bioremediation sector, biotechnology in the farming sector for non-food purposes, and forestry (Dorocki, Brzegowy 2014).

On the basis of the above premises, this article is devoted to analysing the distribution of biotechnology centres in Germany. The choice of Germany as the field for this study was prompted by the dominance of Germany on the European biotechnological market and is an example of an achievement of a regional policy aimed at activating local business and academic communities and connecting the scientific and the business zone. These actions were to bring about the development of biotech production clusters, which Germany considers its regional development instrument. Both R\&D centres and biotech industry plants were taken into account when analysing the distribution of biotechnology centres. This 
article seeks to confirm the spatial compatibility of location of both types of institutions and their concentration. The analysis is based on data published in specialist Internet information services as well as in sectoral reports and studies.

\section{Biotechnology around the world}

Because of its interdisciplinary nature and links with other industries, it is difficult to come up with one clear and unequivocal definition of the biotechnology sector (Dawidko 2012). This author defines biotechnology as the application of technological processes which, using living organisms or their components, produce or modify products for specific use. Therefore, biotechnology is an interdisciplinary science which integrates natural sciences and engineering.

In Western Europe the biotechnology industry began developing in large corporations in the 1980s. But it was only the late 1990s that saw rapid growth of the sector parallel to the increasing share of small and medium-sized enterprises (SMEs). As early as 2001, the number of European SMEs in the biotechnology sector increased to 1,570 , as against 1,273 operating in the USA (Life sciences and biotechnology 2002). However, the European biotechnology industry continues to fall behind that in the USA. In general, the US sector has a much better working network of scientists, entrepreneurs, managers and investors, facilitating a rapid flow of information both inside companies and institutions and between them (Casper, Murray 2005; Casper 2009). Additionally, the development of the biotechnology sector is stimulated by cultural and 'personal' aspects. Cultural aspects involve the position adopted by the authorities and society on undertaking 'morally sensitive' scientific activities, which is particularly important in the case of initiatives related to genetic modifications, etc. As for personal factors, it is believed that in the case of human capital in the biotechnology sector, the flow of knowledge, in spite of seemingly high professional mobility, remains excessively limited to the spatially concentrated labour market (tacit knowledge) (Saxenian 1999; Saxenian et al. 2003; Dahl, Sorenson 2007). Research also shows that $R \& D$ personnel tends to choose employers locally, which may be related to the personal factor too (Stryjakiewicz 2008) or to scientific activity (e.g. their intention to continue their academic and research career at universities). The main difference between the development of the biotechnology sector in Europe and the USA probably stems from the fact that in the latter the sector is growing thanks to businessmen investing in science and research, while in Europe the development is largely based on using the scientific potential (research of R\&D centres) of private companies or spin-offs linked to scientific centres (Rothaermel, Deeds 2004; Ukropcova, Sturdik 2009). Public institutions in Europe initiate the development of the biotechnology industry, as demonstrated by the fact that in Germany, a country that is a European biotech giant, nearly $75 \%$ of biotechnology companies came to life on the basis of research projects financed from public funds (Müller 2001). Also nearly $60 \%$ of biotechnology patents were patented by universities (Wolf et al. 2010).

Globally, the USA reports the highest number of biotech companies. According to the OECD, in 2011 their number reached 7,900, i.e. about $41.6 \%$ of the global number of such entities (Fig. 1). Advanced West European countries: Spain, France, Germany and the UK, followed in the ranking, accounting together with Australia and Japan for nearly $40 \%$ of biotech companies. In general, the biotechnology industry grew predominantly in the USA and in developed West European and Asian countries. Mexico is the only exception among biotechnology leaders. Its high position in the ranking is due to the stimulation of the development of the biotechnology sector by the state and collaboration with the USA, predominantly in developing GMO (Possani 2003; Wójtowicz, Dorocki 2014). Worth noting is that in the above-mentioned countries the share of dedicated biotech firms which devote at least $75 \%$ of their production of goods and services, or R\&D, to biotechnology, is quite insignificant. The highest share of such companies (more than $80 \%$ ) was reported for Israel, Ireland, Slovakia and Germany, while in Spain or the Netherlands they represent approx. $25 \%$ of all biotech companies. Irrespective of the data base selected, the biotechnological domination of the USA and the EU is confirmed (Dorocki, Borowiec, Boguś 2013). 


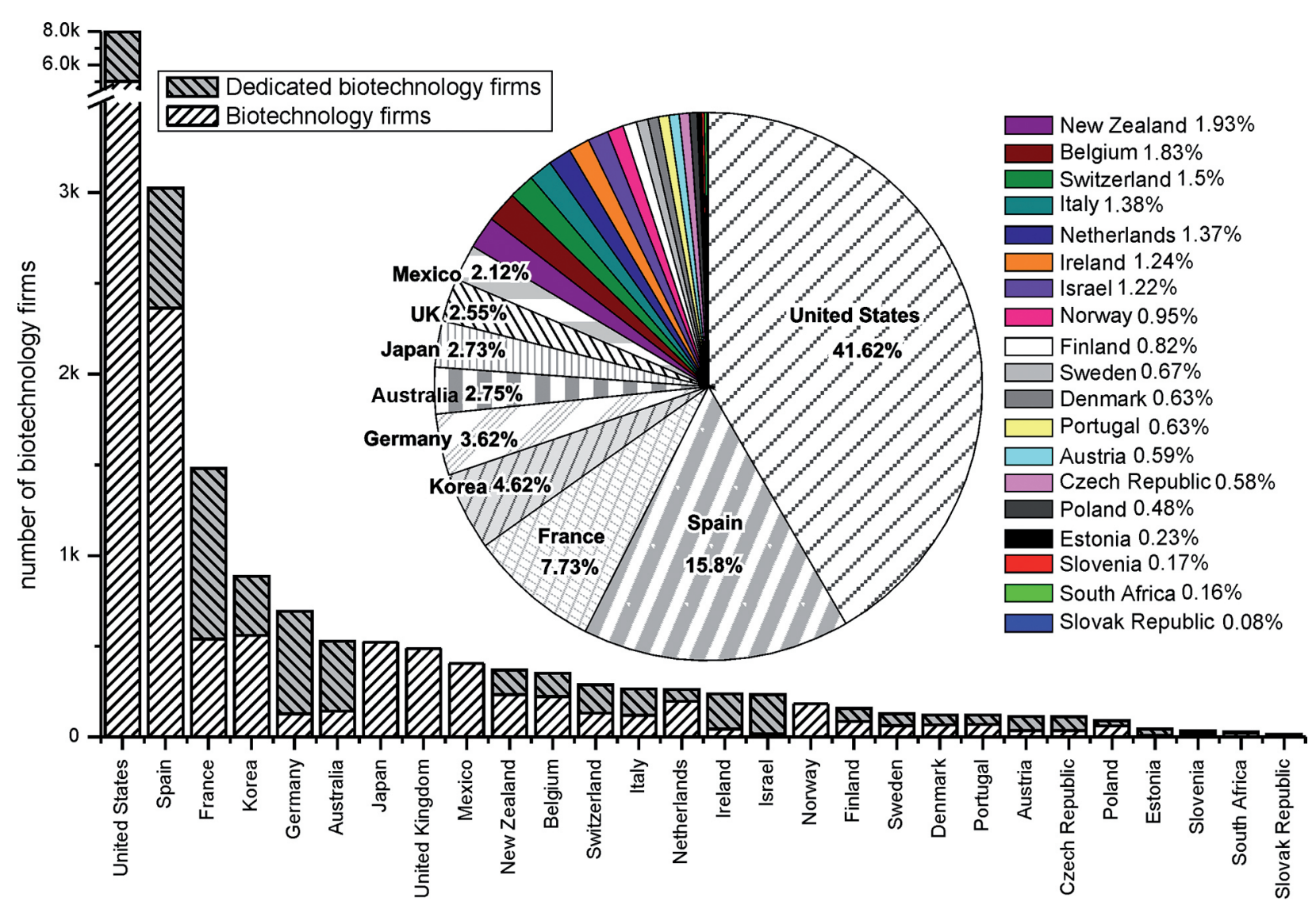

Fig. 1. Number of biotech companies in selected countries as per cent of the total, 2013 Source: own calculations based on OECD data

Also in terms of biotechnology development, the USA is the world leader and, between 2009 and 2011, submitted nearly $39 \%$ of all PCT biotechnological patents. Japan comes second in the ranking, boasting a $12 \%$ share in the pool of global biotechnological patents. Germany is the European leader of the ranking boasting a 7\% share in PCT applications. The dominance of the USA and Western Europe in biotechnological patent applications has been undermined by Canada, China, Korea, India, Israel and East European countries (Fig. 2). The process is similar when considering the geographical location of entities owning patents. The share of the USA as the owner of biotechnological patents submitted between 1998 and 2001 was steadily going down from $56 \%$ to $40 \%$. A similar process was observed in Germany and other West European countries, while Japan and South Korea reported the highest growth in this respect. These changes are particularly important when it comes to the protection of intellectual property rights. This is mainly related to the commercialisation of research, which typically requires long completion dates as a result of difficulties in raising venture capital and attracting investors, as it is assumed that lab research is successful and ends with launching a new product on the market in 1 out of 500 cases (Adelberger 1999). The importance of patent protection is emphasised by the fact that, according to European experts, patent legislation is largely responsible for differences in biotechnology advancement between North America and the EU (Overwalle 2010). Also many scientific institutions (e.g. universities) so far have not taken commercial requirements into account and force scientists to publish their research results before processes related to their legal protection and financing have been completed. The distribution of biotechnological patent applications not only indicates the location of scientific activities in the sector, but also forms the basis for developing biotech companies in a region.

Similarly, in the case of the most scientifically advanced white technology related to the medical application of biotechnology, Asian countries 


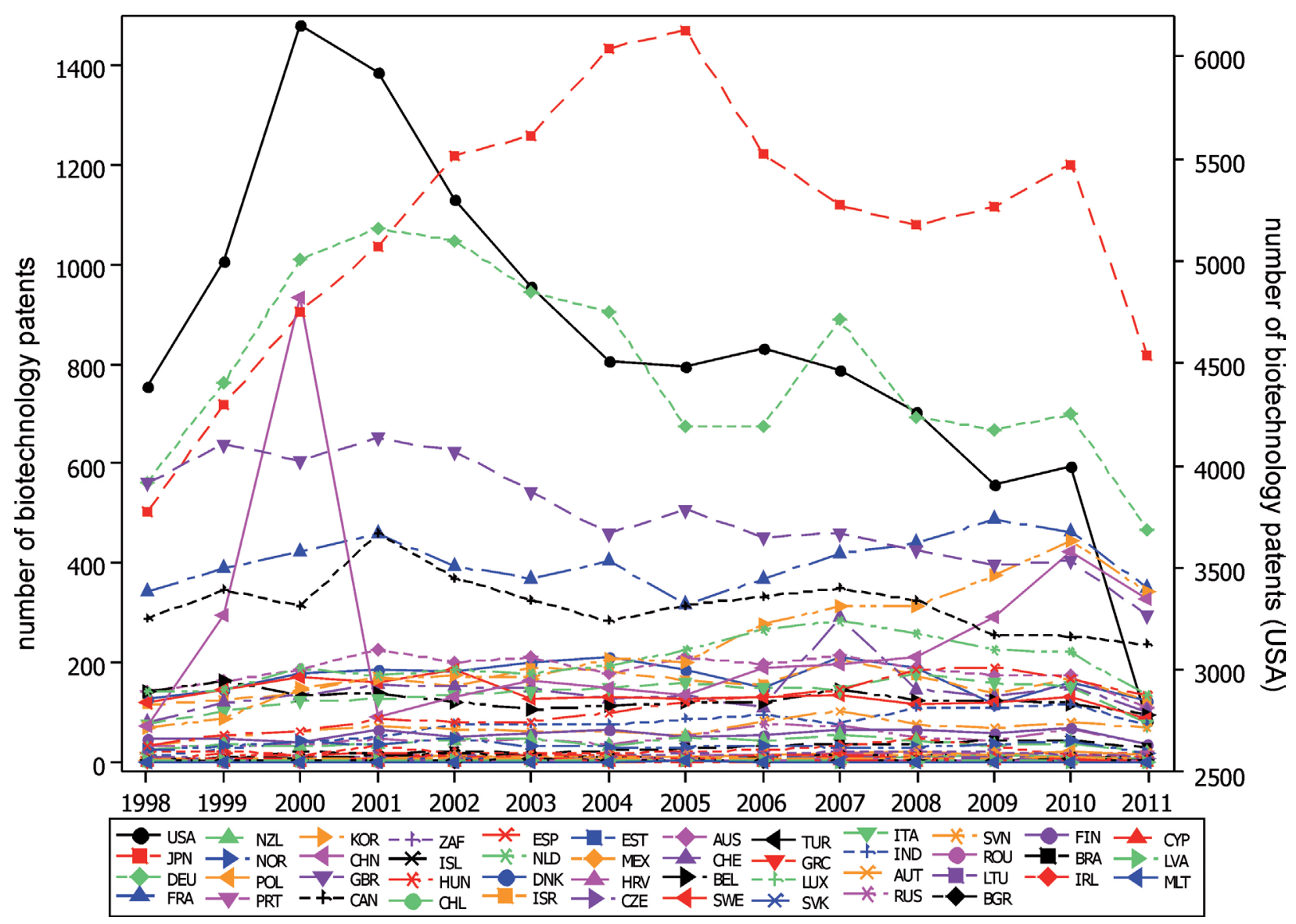

Fig. 2. Number of PCT patent applications in selected countries of the world, 1998-2011 Source: own calculations based on OECD data

including China, Taiwan and Korea dominate globally in terms of the number of clinical researches (Fig. 3). It is connected with technological and scientific progress of areas considered peripheral so far and an increasing outsourcing of research (Higgins, Rodrigues 2006; Howells et al. 2008). This applies mainly to relocating cost-generating stages of the research process (e.g. clinical research) to lower-cost countries (e.g. China, Poland, India). These transformations are particularly notable in Eastern Europe and Asia. Because of its specificity, nowadays biotechnology is developing not only in the traditional economic and scientific centres of advanced states, but also in peripheral and farming regions of developing countries (Dorocki, Borowiec, Boguś 2013).

\section{Biotechnology in Germany}

The German biotechnological industry began to develop in 1970. The authorities recognised bi- otechnology as a sector in the technological and economic development of the country, which affected financing its development. Unfortunately, due to legal impediments and a strong political pressure from the ruling parties, Germany was falling well behind the global leaders. The first action taken in 1978 by the authorities in support of the sector was to adopt guidelines for biotechnology prepared by the National Institute of Health (NIH) and to create the country's own law on genetic modifications. 1984 was the year of the first German in vitro birth and the launch of insulin production based on genetic engineering (Hampel et al. 2001). 1980 and 1990 saw government investment in the development of the biotechnology sector doubled, since it begun to attract attention as an industry of the future, with a foreseeable growth rate of $25 \%$. However, as late as in the early 1990s, Germany was considered the least biotechnology development-friendly country in the Western world (Dohse, Staehler 2008). The state strategy in support of biotech- 


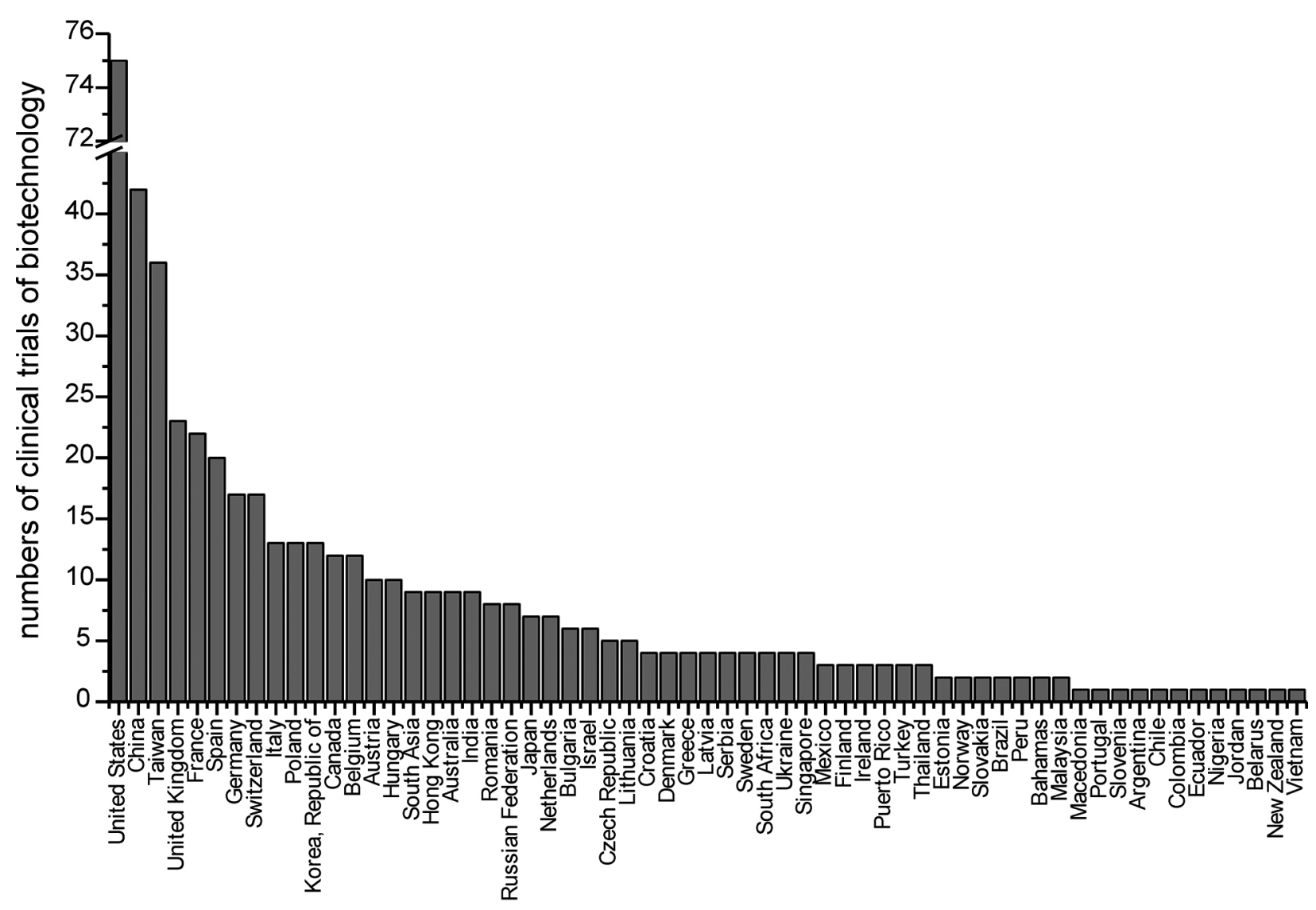

Fig. 3. Number of clinical trials in biotechnology according to the U.P. National Institute of Health Source: own calculations based on U.P. National Institute of Health data

nology development was based on supporting SMEs and connecting the industry and universities while ensuring financial support by banks, which assigned part of their capital for high-risk investment projects. In addition, biotechnology development was stimulated by setting up 17 BioRegios, technologically-oriented regions production clusters forming a network of links between scientific institutions and academics, industry, services, and political and social organisations. Their role was to encourage local entities to collaborate in promoting the entrepreneurial spirit among academics and scientists, and to assist in setting up biotech start-ups and businesses.

The newly created regional formations consisted of both local government and state entities, manufacturing and industrial plants as well as $R \& D$ centres. The structure was different in each BioRegio and did not require the involvement of all types of entities. In extreme cases, it was composed solely of an R\&D centre. Therefore, regions differed in terms of their operational structure and size. Some were composed of single cities with their impact zones, e.g. Freiburg, Jena or Regensburg. Others formed a network of neighbouring cities, e.g. Braunschweig-Gottingen-Hannover, or Heidelberg-Mannheim-Ludwigshafen. On the other hand, the Berlin-Brandenburg region covered the entire federal state. The differentiation caused a difference in the potential of the regions. The most populous Berlin-Brandenburg region had a population of 6 million, while BioRegio Jena reported approximately 100,000 inhabitants. Geographically, the majority of other regions were located in the core industrial districts of Germany: Region Rhein-Main with Wiesbaden, Frankfurt, Darmstadt and Mainz, or Rhein-Neckar-Dreieck with Heidelberg, Mannheim and Ludwigshafen. Only regions such as Greifswald-Rostock and Wilhelmshaven-Oldenburg occupied peripheral areas of the north-eastern and north-western parts of Germany. As a result of a competition based on the biotechnological competitiveness of regions, three were selected: Munich, Rhineland and Rhein-Neckar, to 
receive a public aid of $€ 76.7$ billion and serve as best-practice cases. The Jena region of the former GDR joined the three regions as an example of a successful use of biotechnology in the process of the economic integration of united Germany. The process was to lead regions to achieve specialisation in developing biotechnology. In 1999, on the basis of an operational analysis of the bioregions, those which had achieved regional competitive advantage were selected. They were clusters in Berlin, Hannover and Stuttgart. A total of $€ 50$ million were allocated to these regions by the Federal Ministry of Education and Scientific Research (Dohse, Staehler 2008).

As a result of activities taken by the government, the number of small and medium-sized biotech companies doubled in the late 1990s (Fig. 4). In 1999, Germany reported the highest number of start-ups in the life-sciences sector in Europe. The growth was also attributed to growing outsourcing by large pharmaceutical companies, with $20 \%$ of their research processes delegated outside (Adelberger 1999).

The biotechnological development of Germany in the discussed period resulted mainly from the fact that, from the onset, federal government efforts focused on assuring high-quality basic research in biotechnology and its commercial application. To this end, public research labs were financed by offers of funds, mainly for basic research at universities. As early as 1975, the state authorities set up the Organisation for Biotechnology Research (GBF) integrating research centres with nearly 600 scientists. The leading German centres were: Max-Delbrueck, the Centre

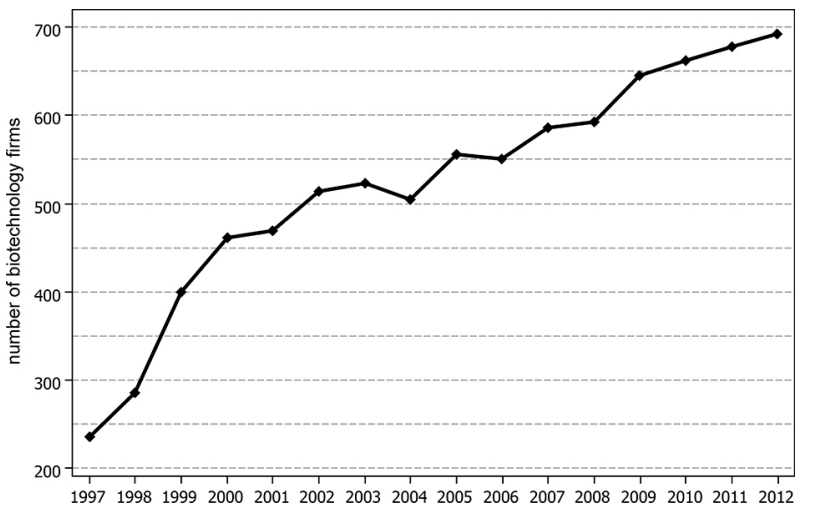

Fig. 4. Number of biotech companies in Germany, 19972012

Source: own calculations based on Dohse (2000) and the Internet portal biotechnologie.de for Molecular Medicine (MDC) in Berlin, the GSF Research Centre for Environment and Health in Munich, and the German Cancer Research Centre in Heidelberg. From 1997 to 2007, the budgets of those institutions, financed both by the federal government and regional authorities, went up by $33 \%$ compared with the average growth of $15 \%$ in other centres (Rammer et al. 2008).

Next, efforts towards developing biotechnology involved the commercialisation of basic research accompanied by the development of entrepreneurship in academic circles. The number of dedicated biotech firms (dBFs) in Germany went up rapidly from 250 in 1997 - the year of the first payments under the BioRegio programme to more than 500 in 2002. Biotech companies appeared predominantly in regions which received state subsidies. In 2006, 145 out of 494 dBFs were located in seven regions selected in competitions (BioRegio), while 135 operated in other regions. The increase in the number of biotech companies in the above-mentioned seven regions occurred largely at the initial stage of financing (19982003), when the regions received the highest financial support (Häussler, Zademach 2007). The biggest chunk of total BioRegio financing (more than $60 \%$ ) went to private companies, most of them start-ups. Consequently, approximately $2 / 3$ of all companies co-financed under the BioRegio programme were set up in 1997 or later, i.e. during BioRegio exploitation. In the case of other regions, the beneficiaries were mainly public institutions (universities, research centres, community organisations), while private biotech companies received $37 \%$ of the total funds. In the light of the above, it is hardly surprising that the number of $\mathrm{dBF}$ s was growing faster in the promoted regions than in other parts of Germany, while in other bioregions the growth was comparable with the remaining part of the country. Similarly, the annual employment growth rate from 1998 to 2006 in the seven supported regions remained considerably higher $(11.8 \%)$ than in other bioregions $(3.3 \%)$, while the national average was $2.4 \%$.

Biotechnological development in Germany was initiated chiefly through state support and bank loans. Private investment (venture capital, VC) in the sector grew as late as the mid-1990s. 1995 to 2000 saw over a 10-fold increase (from 


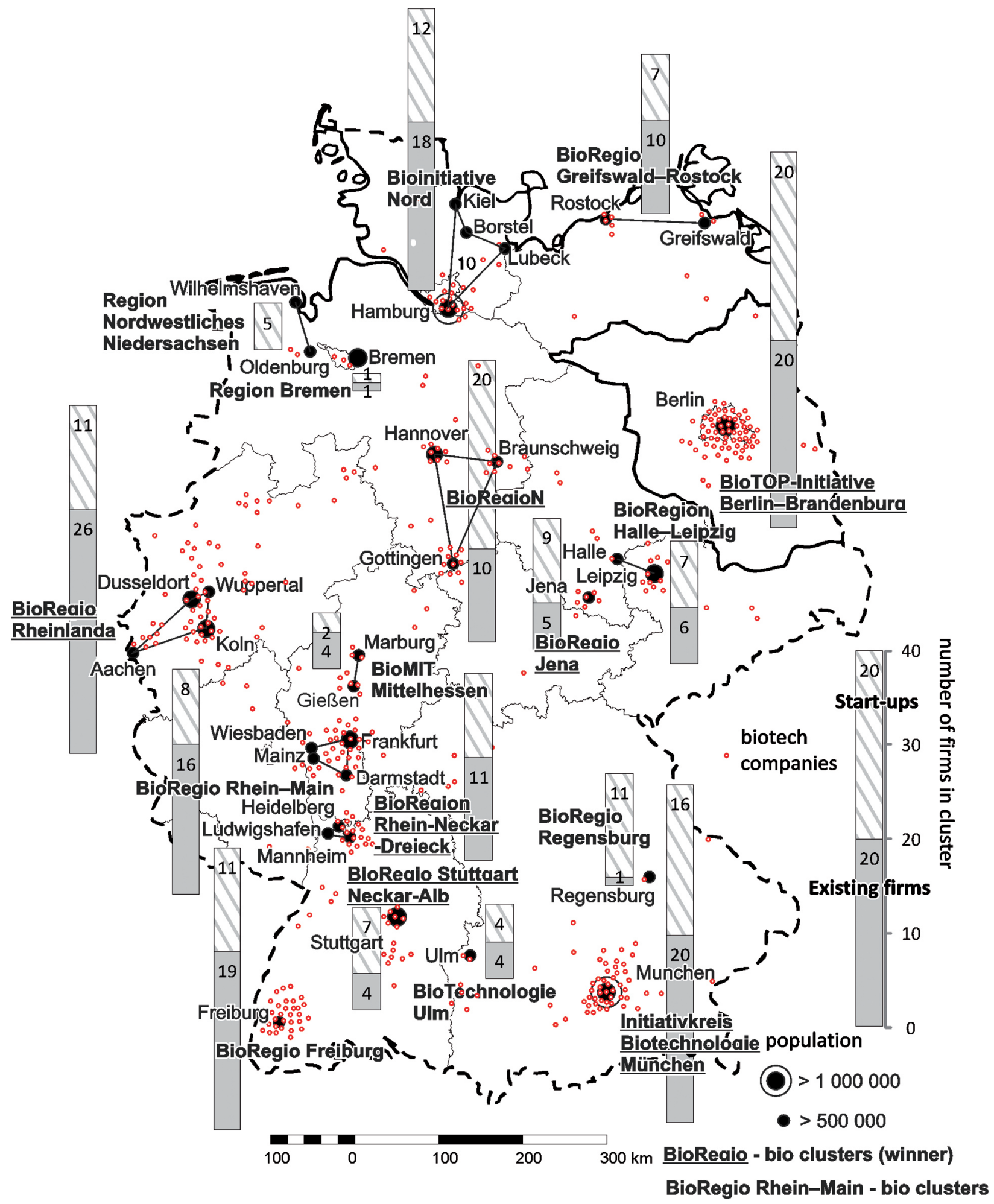

Fig. 5. German biotech clusters in 1996, the distribution of biotech companies (one dot can represent one or more companies) and their change 1996-1998

Source: own studies on the basis of Dohse (2000)

$€ 50$ million to nearly $€ 500$ million) in the VC value in biotech companies. Geographically, private investment would mainly go to previously created regions supported by the state. The average number of private venture-capital investments in companies formerly co-financed under BioRegio was higher by as much as $60 \%$ than the average VC amount invested in companies without state 


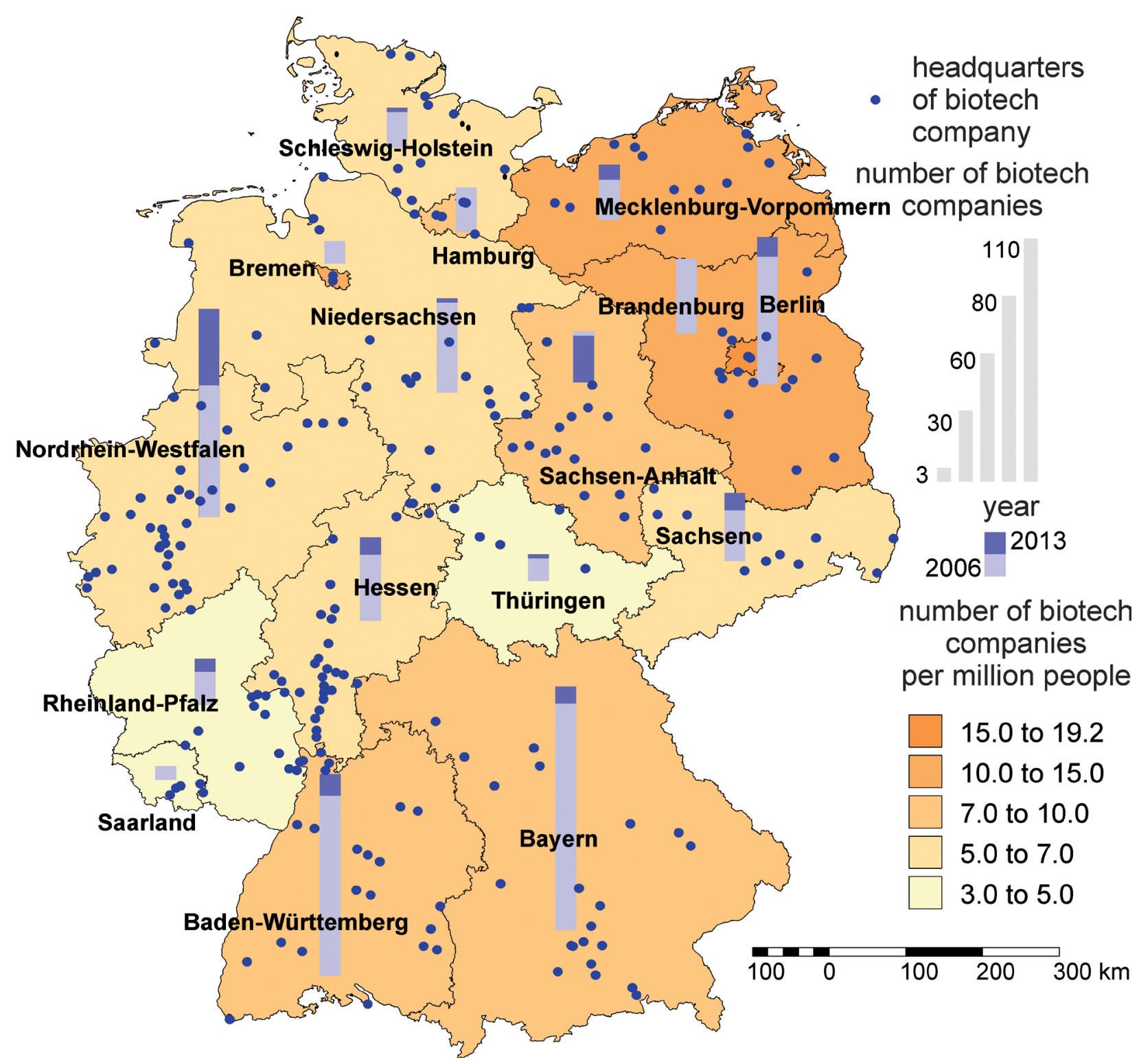

Fig. 6. Regional distribution of biotech companies in 2005 and 2013, and per million people Source: own calculations based on the Internet portal biotechnologie.de

support. This shows that BioRegio financing had a considerable impact on attractiveness to private investors. Of the seven regions, from 1995 to 2005, the highest number of investors were attracted by Munich (approximately €900 million, nearly $37 \%$ of the value of total investment in the region). In the ranking by VC invested, Munich was followed by Rhein-Neckar (Heidelberg) (€400 million), Berlin (approximately $€ 300$ million), and Rhineland (approx. €250 million). The observed increase in investment and cash flows shows that the regions have external openness. The process, leading to the creation of links and relations via collaboration, as well as relationships and interaction between entities inside and outside a cluster, influences the efficiency and contributes to the competitiveness of the cluster. Also in the area of science, the selected regions received nearly $50 \%$ of their total funds from the German Science Foundation (Deutsche Forschungsgemeinschaft, DFG).

Summing up the first period of biotechnology development in Germany, one may say that it occurred mainly in regions which received government support, including mostly seven regions: Berlin, Munich, Rhineland, Jena, Lower Saxony (Niedersachsen), Stuttgart, and Rhein-Neckar. Among the regions, Berlin and Bavaria (Bayern) 


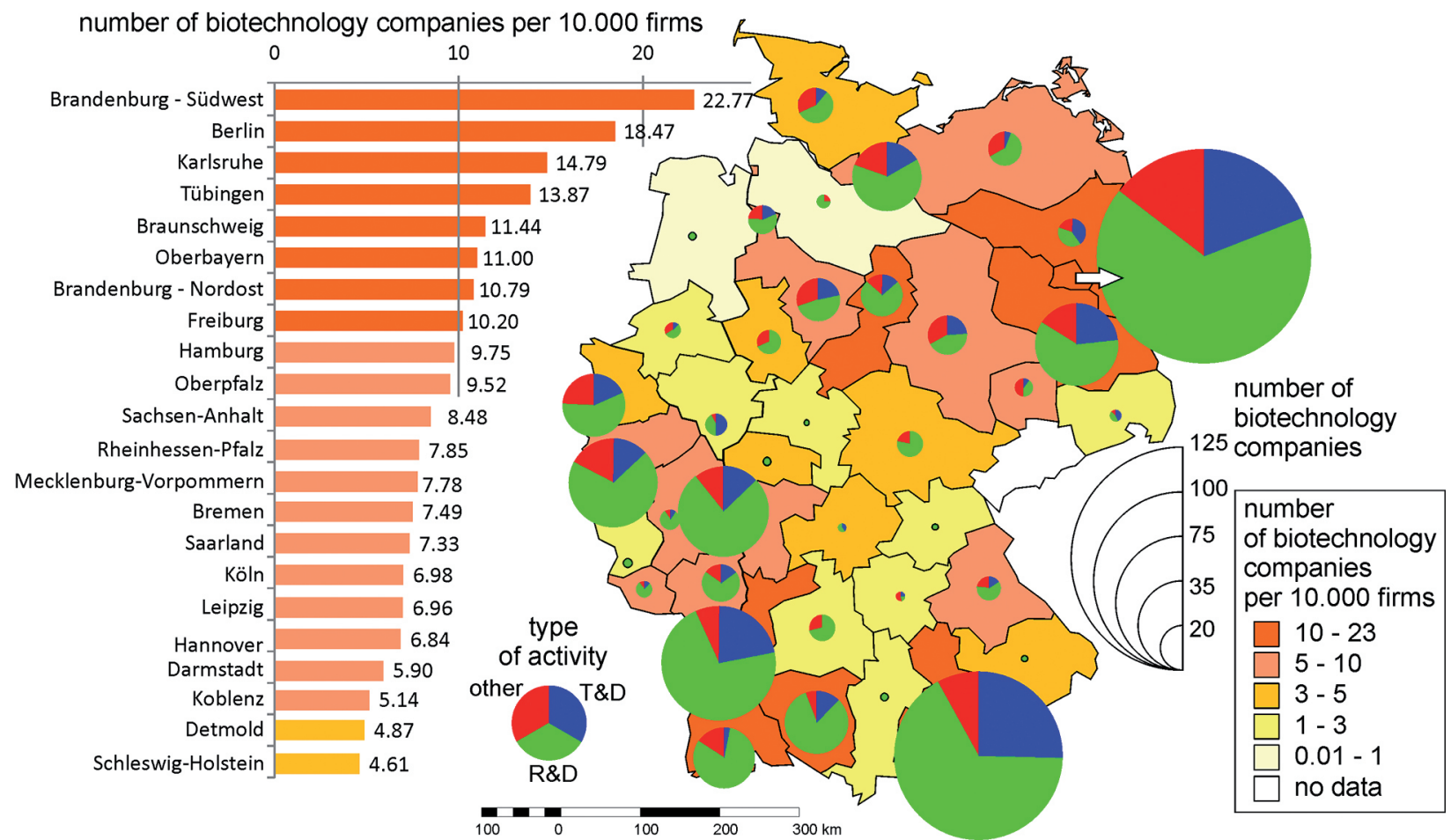

Fig. 7. Change in the number of biotech companies, 2005-2013 (2005=100) Source: own calculations based on the Internet portal biotechnologie.de

with Munich were the main poles of biotechnology growth.

In the years that followed, the spatial distribution of biotechnology centres did not change significantly. Most regions reported growth of $\mathrm{dBFs}$ between 2006 and 2013. The highest number of biotech companies were set up in the most bio- logically developed regions of Germany: Nordrhein-Westfalen (35 companies) as well as Bavaria (12), Baden-Württemberg (10) and Berlin (9) (Fig. 6). However, when compared with 2005, the highest average growth in the analysed period was recorded in regions below the top companies in the German biotechnological ranking: Rhein-

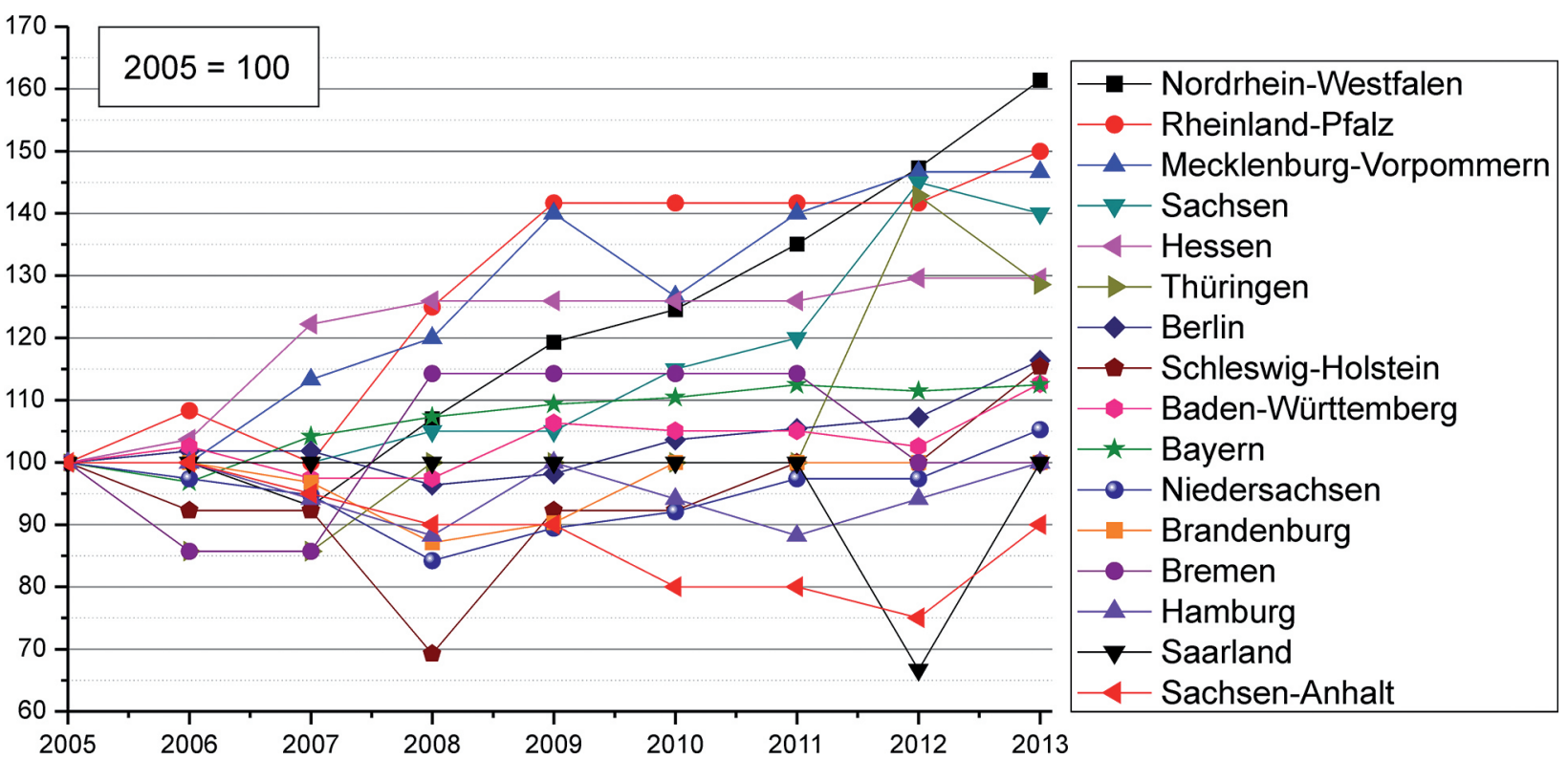

Fig. 8. Biotech companies per 10,000 firms and their structure in 2011 Source: own calculations based on the Internet portal biotechnologie.de 


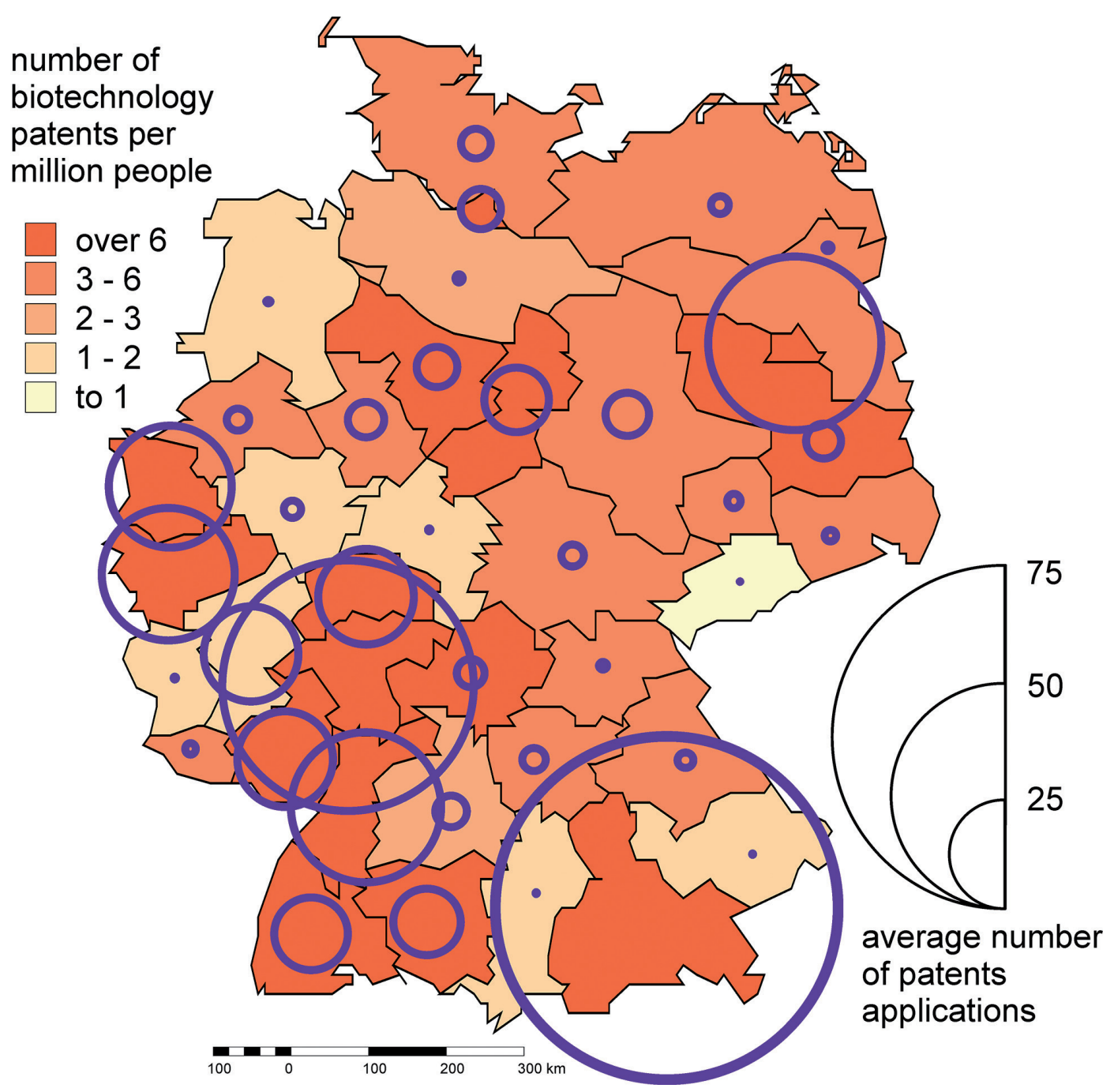

Fig. 9. Average number of patent applications in the regions of Germany, 1990-2010 Source: own calculations based on Eurostat

land-Pfalz reporting the average growth of $29 \%$, Mecklenburg-Vorpommern growing at $27 \%$, and Hessen at $23 \%$.

Sachens-Ahnalt was the only region reporting a drop in the number of biotech companies (Fig. 7). In spite of such substantial growth in their number outside the leading biotechnology centres in Germany, their structure has not changed significantly. Invariably, Bavaria hosts nearly $20 \%$ of the companies, $15 \%$ are based in Baden-Württemberg, and $11 \%$ in Berlin. Only Nordrhein-Westfallen recorded distinctive growth in its share of the total number of biotech companies, from $11.5 \%$ in 2005 to $16.2 \%$ in 2013 . In other cases, the shares changed only slightly.

In the category of regions (NUTS 2), Germany ranks among European leaders with its share of biotech companies per 10,000 firms, after the British Merseyside region with the MerseyBIO cluster (Dorocki, Jastrzębski 2012; Fig. 8). Those are largely the urban regions of Brandenburg and Bavaria, which overlap with the leading biotechnology centres of Germany. In most regions, R\&D service companies ${ }^{1}$ prevail, hand in hand with biotech companies operating in the therapeutic and

$1 \quad$ R\&D companies provide supporting services, such as product development, analytical services, screening, production, as well as R\&D services for the biotechnological industry. However, some companies may both, work on drug development and offer services at the same time. In that case, the main field of a company's operation prevails. 
diagnostic sector ${ }^{2}(T \& D)$, which illustrates high scientific and technological advancement of these regions. Other biotech companies, not involved in research on treating humans, focus on farming, cosmetics, environmental protection, food technology, industrial biotechnology, naturceutic or veterinary problems; they were the least represented in the structure of most German regions.

The regional distribution of biotechnological patents in Germany copies that of the biotechnology industry, which confirms the interaction between research and production. The supremacy of large metropolises in developing biotechnological innovation is confirmed by the average number of biotechnological patent applications over the years 1990-2010 (Fig. 9) in regions with large agglomerations that are simultaneously business, commercial and R\&D centres. First and foremost, this would be the region of Upper Bavaria with Munich (the Max Planck Institute for Biochemistry), Darmstadt with Frankfurt am Main (the Max Planck Institute for Biophysics) and Berlin (the Biotechnology Training Centre). This indicates that regions that lead in the rise in the number of patent applications are those with great human capital, tertiary education institutions/ universities and R\&D, as well as high commercial potential allowing direct transfer of innovation to production and service companies (Fig. 10). This dependence is confirmed by analyses of regional differences in human potential in Europe (Borowiec et al. 2009) and in economic potential (Rachwał 2013).

The importance of the economic potential for developing the biotechnology sector is confirmed by the regional distribution of biotech plants and $R \& D$ centres in Germany. Out of all regions, the highest number of biotech institutions is located in south-western Germany: Nordrhein-Westfalen (243), Bavaria (229) and Baden-Württem-

\footnotetext{
2 The key task of T\&D companies is to use biotechnology for discovering and developing innovative therapeutic compounds and analysing compounds in terms of their applicability in medicine. These companies must have their own R\&D departments and infrastructure required to develop innovative drugs. Their operation focuses on developing innovative therapeutic compounds. This category does not include enterprises which are only drug producers or distributors, have no research department of their own, and only deal with generic drugs and do not develop innovative therapeutic compounds.
}

berg (220) as well as Brandenburg with the Berlin region (166 jointly) (Fig. 10). The fewest biotech institutions can be found in the northern and central regions. The regional structure is dominated by biotech enterprises and universities/colleges, while the share of independent research centres is the lowest. Biotech companies (and dedicated $\mathrm{dBF}$ in particular) in most cases have their own research base, like universities and colleges. In terms of distribution, institutions of the $R \& D$ sector have the highest share in regions with the lowest biotechnological potential, which confirms that biotechnology develops through the commercialisation of science and collaboration between industrial sectors and science.

When analysing the distribution of cities with biotechnological centres in 2013, one can see that they tend to be located in regions set up in the late 1990s (BioRegio). Activity in the field of biology was reported in 219 cities and towns from Berlin in the east to Westfallen in the west, and from Hessen to Württemberg and Bavaria in the south (Fig. 11). In addition, one can see their concentrations in the Leipzig-Halle industrial district and in large agglomerations such as Hamburg or Dresden. There are also some outstanding scientific centres such as Rostock or Freiburg. Berlin and Munich stand out among cities for the number of centres and institutions they host. Generally, large cities - seats of leading scientific and research institutions - dominate, while the share of biotech industry institutions is fairly significant in smaller towns with a population of 50,000 or smaller. When analysing the spatial concentration of the biotechnology sector, its highest concentration is found to be related to universities and research institutes, while their highest dispersion is reported for other biotech companies and vocational colleges.

The above shows that biotech plants are located mainly in scientific centres. This is confirmed by an analysis of the coexistence of biotech institutions from the manufacturing and R\&D sectors. Generally, when analysing both academic institutions and labs, the canonical correlation is 0.818 . When identifying elements, note the highest correlation of dedicated biotech companies and universities (Fig. 12). In addition, the impact of the size of a city on the location of biotechnology activity, confirmed for universities and dBFs, 


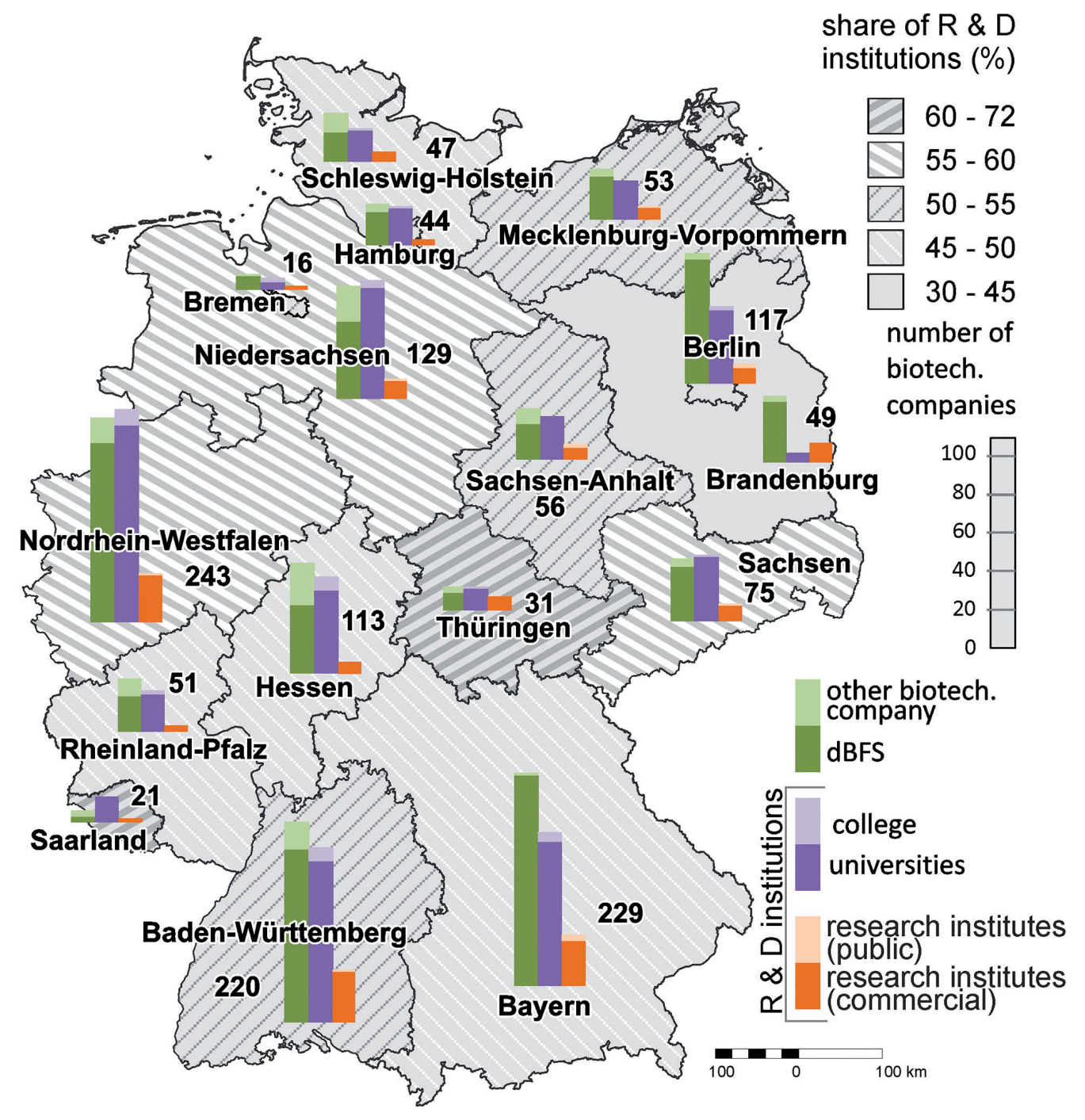

Fig. 10. Structure of biotechnology centres in the regions of Germany, 2013 Source: own calculations based on the Internet portal biotechnologie.de

was analysed. Given the results of the canonical correlation obtained in the analysis, the coexistence of $\mathrm{dBF}$ and private research institutes and universities in German towns was examined. The results show that one can speak of a strong interaction between the specialist biotechnology industry and universities. This confirms a strong link between the basic research stage and the stage of production in the biotechnology sector.

In order to identify the leading biotechnology centres of Germany, cities were grouped by using the k-mean method in order to come up with the ranking (Fig. 13). Berlin came first. Its cluster is made up of the city of Berlin and its 9 satellite cities dominated by the capital. This indicates that this is actually a single metropolis region. The district is dominated by dFBs and universities oper- ating largely in white (medical) biotechnology. In this way, Berlin is the world's medical research centre in the global top 10 biotech clusters of 2011, ranking 8th globally and 2nd in Europe after the international BioValley cluster. Berlin is the seat of important research institutes, including BiotechPark Berlin-Buch with the Max Delbrück Centre for Molecular Medicine (MDC), the Leibniz Institute for Molecular Pharmacology (FMP), and the Experimental Clinical and Research Centre (ECRC).

The Munich region comes next in the ranking. Apart from Munich, the region consists of 10 locations, including Martinsried, an important biotechnology centre. They form a part of the Bavaria bio-cluster. When compared with Berlin, there are many research centres in the region apart from 


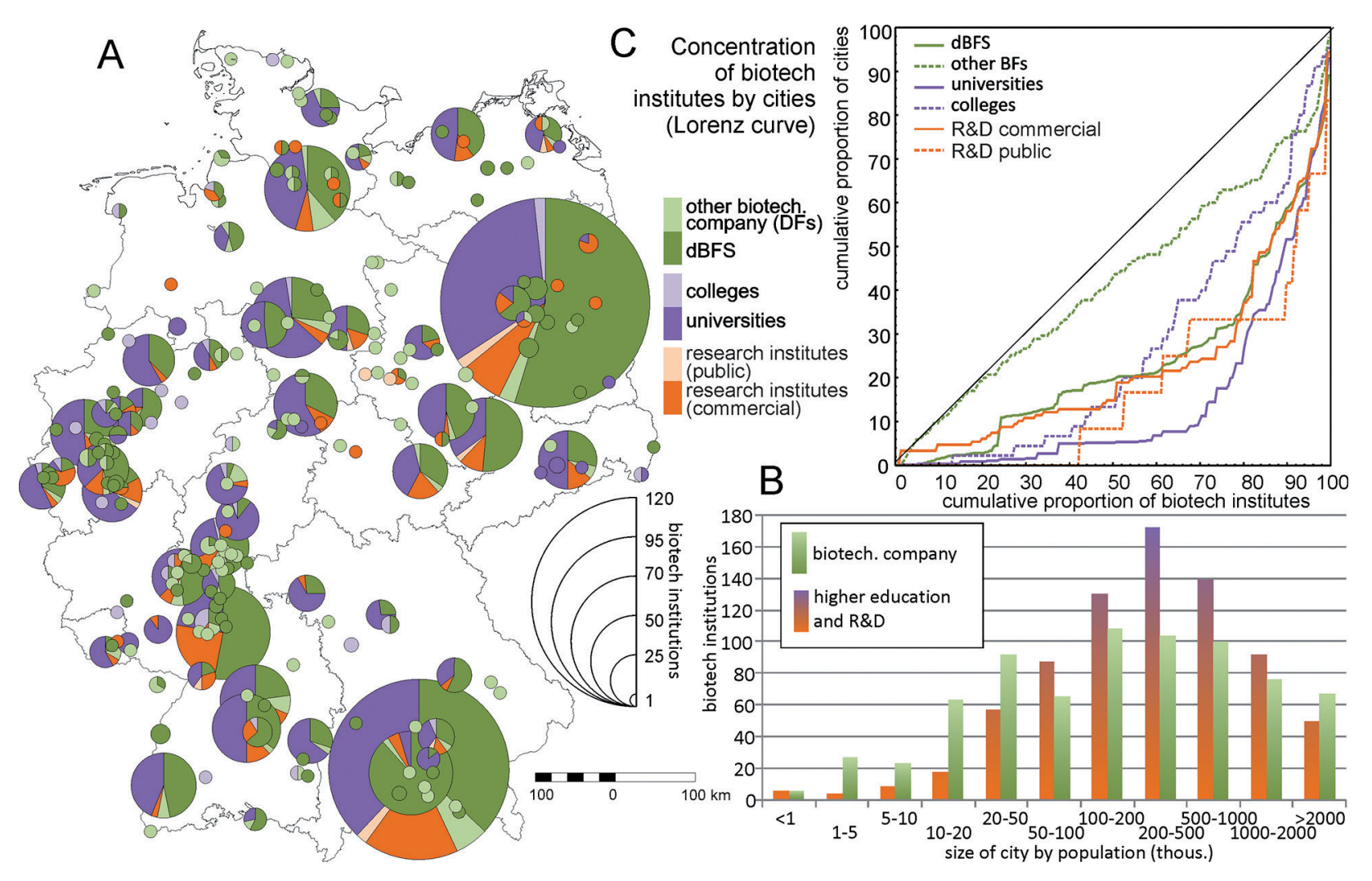

Fig. 11. Distribution of cities and biotech institutions (A), city size structure (B), and concentration (C) of biotech institutions in Germany, 2013

Source: own calculations based on the Internet portal biotechnologie.de

$\mathrm{dBF}$ and universities, which can be the reason for the number of biotechnological patents being higher here than in Berlin. The Munich Biotechnology Cluster is the leader of the centre, which also includes the Foundation of Grosshadern University Clinic as part of Ludwig-Maximilians-Universität (LMU), the Max Planck Institute of Biochemistry in Martinsried, and the Foundation of the Gene Centre Munich as one of four centres for applied molecular biological research in Germany. The state BioRegio initiative, coupled with the establishment of the Life Science Centre Weihenstephan of the Technische Universität München (TUM) in 2000, has stimulated the development of the sector. Both Berlin and Munich are biotechnology centres clearly ahead of other centres in Germany. Since Munich and Martinsried form a bi-polar system, no competitive biotechnology centres have developed in their surroundings ( $\mathrm{Zi}$ oło 2003).

Other biotechnology centres in Germany do not have one clearly dominant core but are composed of very many locations representing dif- ferent biotechnology potentials. The centres are described as poly-bioclusters. Among the largest clusters of this type is the region stretching from Marburg in Hessen to Heidelberg in Baden- Württemberg in the south. It forms a longitudinal strip of 35 locations. Heidelberg with its Biotechnology Cluster Rhine-Neckar - BioRN (the Heidelberg Technology Park and the Institute of Pharmacy and Molecular Biotechnology at the University of Heidelberg) is the centre of the region. Apart from research centres, the cluster offers a well-developed chemical and pharmaceutical industry: BASF, Boehringer Ingelheim, Mannheim (now Roche) and Merck, which put it on the right track to development (Krauss, Stahlecker 2001). Other important biotechnology centres are Mainz BioNTech (Biopharmaceutical New Technology) and Frankfurt am Mein with its Innovation Centre for Biotechnology Frankfurt (FIZ). The region hosts many other biotechnology scientific centres as well as numerous biotechnology and industry collaboration networks. The regions boasts a considerable share of biotechnology vocational 


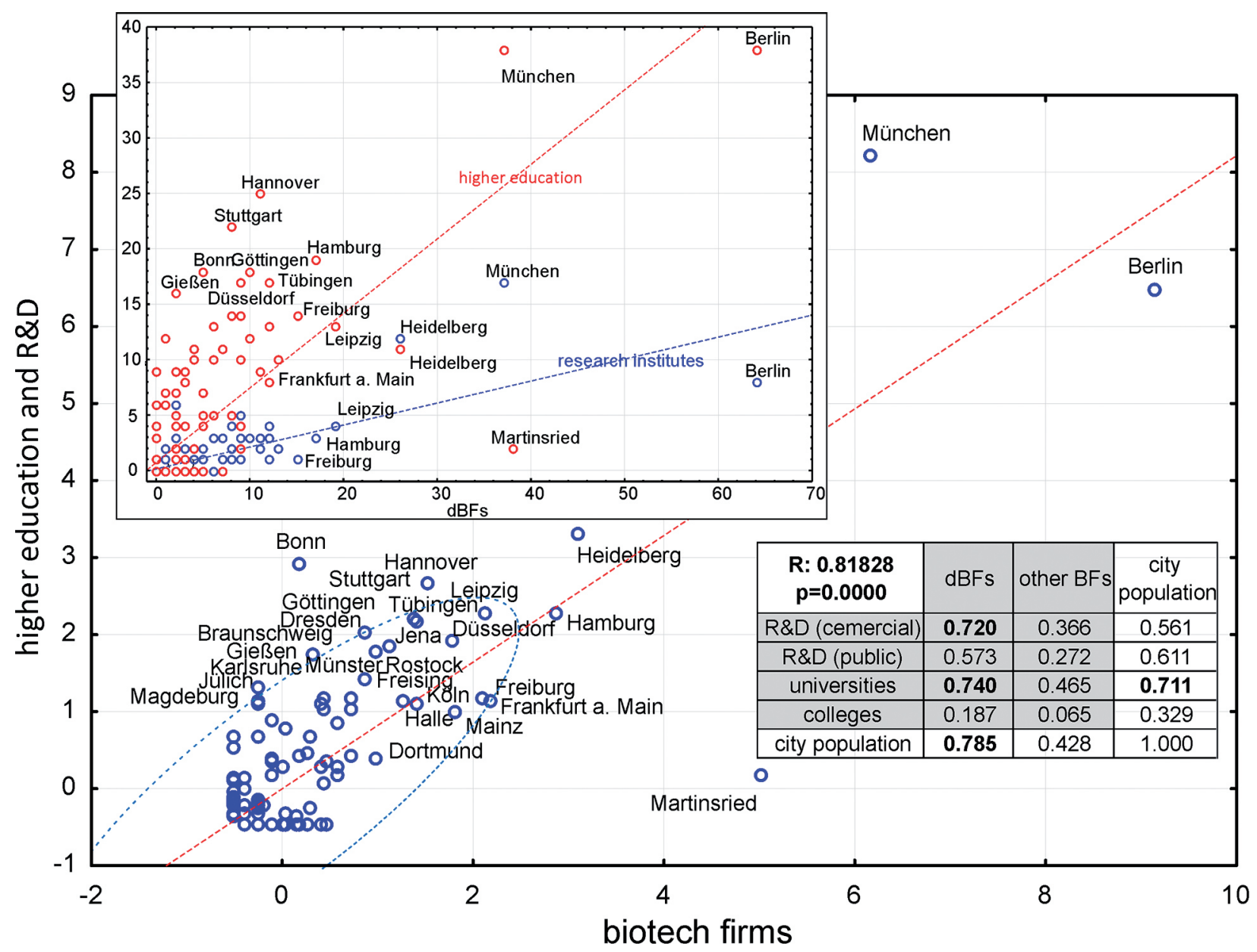

Fig. 12. Dependence between the location of biotech production and R\&D centres in Germany, 2013 Source: own calculations based on the Internet portal biotechnologie.de

colleges and other biotech companies, which indicates the development of less technologically advanced biotech companies.

The next region is Rhein-Ruhra in NordrheinWestfallen, a region with a long tradition of industry. Its leading centres with similar biotechnology potentials are Bonn, Cologne, Düsseldorf and Münster in the north. The region consists of 35 centres, with their heaviest concentration in the Bonn-Düsseldorf strip. It is dominated by universities and research centres operating mostly in the LifeScienceNet Düsseldorf, BioCologne, Der BioIndustry, Clusters für Biotechnologie, Bio.NRW, and the Bio-Tech-Region OstwestfalenLippe.

Another important biotechnology centre in Germany is a region consisting of two centres: Stuttgart and Tübingen. Its other cities are Reutlingen and Esslingen, and the clusters that operate here are BioRegio Stern and BioPro Baden-Württemberg.
Apart from the above-mentioned centres, there are some biotechnology centres of low concentration, different potentials and small shares in biotechnology patents in central Germany. The area can be considered both a set of individual biotechnology centres or as one large centre, and that is why it is described as a multi-biocluster region. Its key centres are Hannover in Lower Saxony with BioRegioN and Göttingen with Georg-August-Universität Göttingen, as well as Leipzig (Bio City Leipzig) and Halle (Bio Mitteldeutschland) in Saxony. The first two are dominated by scientific centres, while in Saxony the key role is played by biotech companies. Other 25 locations of the regions are seats of biotech companies representing low potential for development.

Other centres where biotech institutions are located do not form clearly identifiable centres, or they offer low biotechnology potential. Only Rostock and Freiburg can be referred to as bio- 


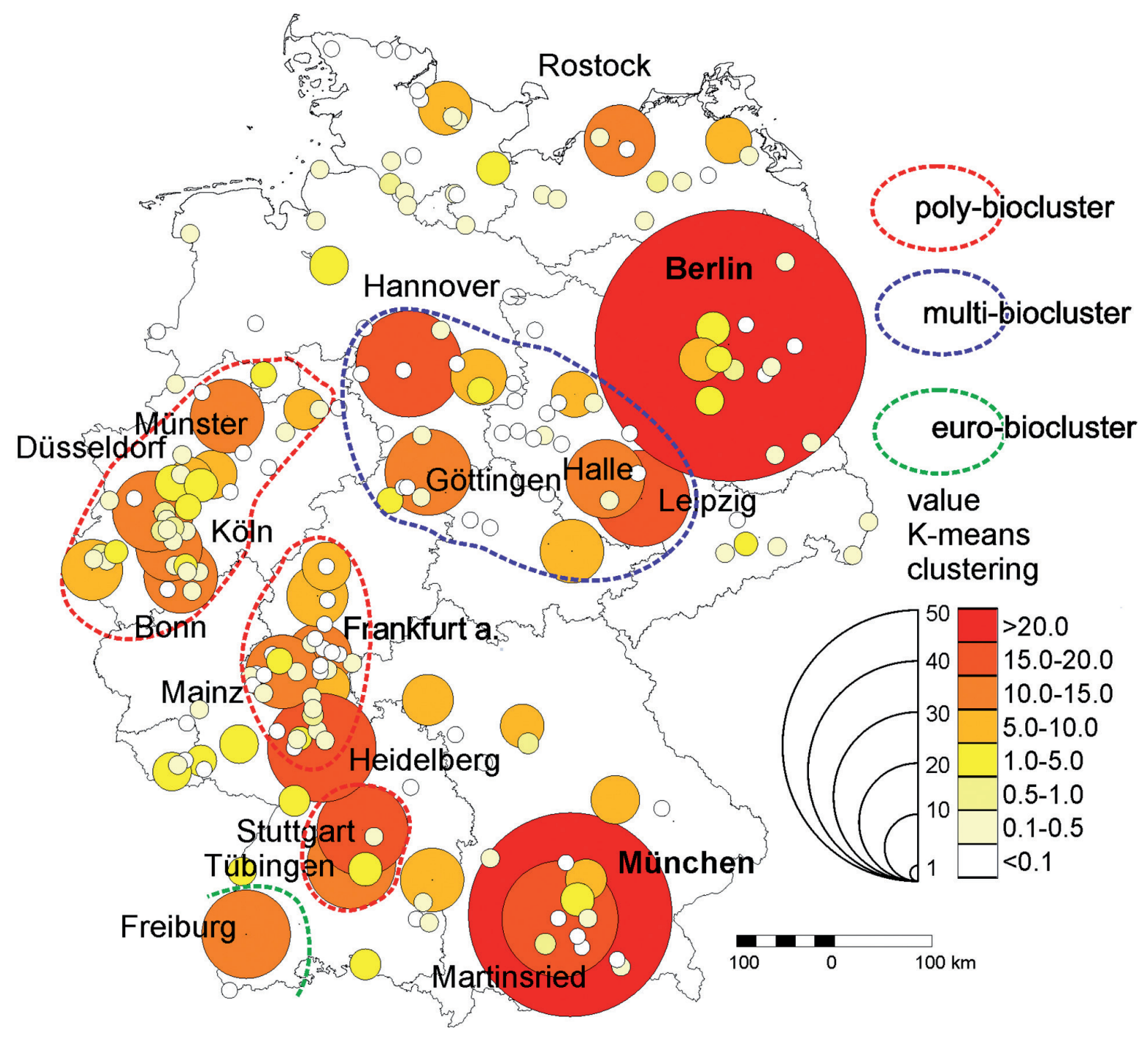

Fig. 13. Biotechnology centres in Germany, 2013

Source: own calculations based on the Internet portal biotechnologie.de

technology centres as such. In the case of Rostock, its biotechnology potential is created largely by scientific institutions, including the University of Rostock and the BioCon Valley Mecklenburg-Vorpommern. In turn, Freiburg is part of the European international BioValley cluster made up of such centres as Basel (Switzerland) and Strasbourg (France).

Although they form bioregions and have large agglomerations with numerous biotechnology institutions, north Germany, eastern Hessen and Thüringen, and southern Saxony have failed to develop strong biotechnology centres. This can indicate a competitive advantage of centres located in former East Germany, which early received the highest financial support. Other factors can include cultural aspects connected with the spir- it of entrepreneurship and social capital, whose role in the commercialisation of tasks and setting up start-ups cannot be underestimated. Besides, as in the case of Lower Saxony, the general economic condition, in addition to human capital and scientific institutions, seems to have a decisive impact on developing biotechnologies.

\section{Summing up}

The spatial distribution of biotechnology centres in Germany is characterised by heavy concentration. The Berlin and Munich agglomerations with their satellite cities are the main poles of biotechnology centres development. In other cases, biotechnology centres are parts of clusters 
differing in size and specialisation. The spatial proximity of biotech plants, centres and institutions confirms the need for a strong interaction of biotech entities. The largest German biotechnology centres have developed as a result of stimulation by the state and setting up BioRegios, which mainly offer financial support to new investment projects. Scientific institutions, predominantly universities, are the factor which has determined the development of German biotechnology. They ensure both competitive scientific solutions as well as adequately educated staff. Another important factor is the level of economic development. Its growth creates new possible interactions between R\&D centres and the industry. For this reason, advanced biotechnology develops mostly in large, economically robust and vibrant agglomerations and in the traditional industrial sectors. In the case of the so-called other biotech companies, public research institutions and higher vocational schools, their distribution is less connected with large agglomerations and they are characterised by lower spatial concentrations of locations. Finally, note that in Germany the growth of biotechnology has been largely stimulated by the state policy, which has created biotechnology centres on the basis of the existing R\&D centres and the biotechnology industry closely related to them, i.e. a successful combination of money and ideas.

\section{References}

Adelberger K.E., 1999. A developmental German state? Explaining growth in German biotechnology and venture capital. BRIE Working Paper 134.

Aharonson B., Baum J., Plunket A., 2008. Inventive and uninventive clusters: The case of Canadian biotechnology. Research Policy 37(6-7): 1108-1131.

Bauer M., 1995. Resistance to new technology and its effects on nuclear power, information technology and biotechnology. In: Bauer M. (ed.), Resistance to new technology: Nuclear power, information technology and biotechnology. Cambridge University, Cambridge: 1-42.

Baum J.A.C., Silverman B.P., 2004. Picking winners or building them? Alliance, intellectual, and human capital as selection criteria in venture financing and performance of biotechnology startups. Journal of Business Venturing 19: 411-436.

Béliveau D., Haskell N., Veilleux P., 2011. Alliance partner selection criteria in emerging markets: Theoretical foundations and propositions for research in the biotechnol- ogy sector. American Society of Business and Behavioral Sciences 18(1): 1048-1065.

Beuzekom (van) B., Arundel A., 2009. OECD biotechnology statistics 2009. Online: http:// www.oecd.org/ sti/scitech/42833898.pdf (accessed 11 February 2014).

Borowiec M., 2008, Rola kapitału ludzkiego w procesie podnoszenia konkurencyjności układów przestrzennych (Role of human capital in increasing the competitiveness of spatial systems). Rozprawy Naukowe Instytutu Geografii i Rozwoju Regionalnego Uniwersytetu Wroctawskiego 3: 9198.

Borowiec M., Dorocki P., Jenner B., 2009. Wpływ zasobów kapitału ludzkiego na kształtowanie społeczeństwa informacyjnego i innowacyjności struktur przemysłowych (Effect of human capital resources on the creation of information society and the innovativeness of industrial structures). Prace Komisji Geografii Przemystu Polskiego Towarzystwa Geograficznego 13: 95-109.

Borowiec M., Dorocki S., 2011. Rola kapitału ludzkiego w procesie kształtowania innowacyjności układów regionalnych Francji (Role of human capital in the development of innovative regional systems of France). Rozprawy Naukowe Instytutu Geografii i Rozwoju Regionalnego Uniwersytetu Wroctawskiego 19: 215-230.

Casper P., 2009. The marketplace for ideas: Can Los Angeles build a successful biotechnology cluster?. A Report to the John Randolph Haynes Foundation, Keck Graduate Institute of Applied Life Sciences. Online: http:/ / www.kgi.edu/ Documents/ In_the_news/ Casper\%20Biotech\%20Report\%20Final.pdf (accessed 11 February 2014).

Casper P., Murray F., 2005. Careers and clusters: Analyzing the career network dynamic of biotechnology clusters. Journal of Engineering and Technology Management 22(1): 51-74.

Chojnicki Z., Czyż T., 2006. Aspekty regionalne gospodarki opartej na wiedzy w Polsce (Regional aspects of the knowledge-based economy in Poland). Bogucki Wydawnictwo Naukowe, Poznań.

Chojnicki Z., Czyż T., 2008. Gospodarka oparta na wiedzy jako czynnik rozwoju regionalnego (Knowledge-based economy as a factor of regional development). In: Stryjakiewicz T., Czyż T. (eds), O nowy kształt badań regionalnych w geografii i gospodarce przestrzennej. Biuletyn KPZK PAN, 237, PWN, Warszawa: 146-158.

Cooke P., 2001, Clusters as key determinants of economic growth: The example of biotechnology. In: Mariussen $\AA$. (ed.), Cluster policies - cluster development? Nordregio Report 2, Stockholm: 23-38.

Corolleur F., Mangematin V., Torre A., 2003. French biotechnology start-ups and biotechnology clusters in France: The importance of geographic proximity. In: Fuchs G., Luib B. (eds), Biotechnology in comparative perspective: Growth and regional concentration. Routledge, London: 221-257.

Czyż T., Chojnicki Z., 2008. Gospodarka oparta na wiedzy w regionach metropolitalnych $i$ aglomeracjach miejskich w Polsce (Knowledge-based economy in the metropolitan regions and urban agglomerations in Poland). Studia KPZK PAN 120, Warszawa: 74-95.

Dahl M.P., Sorenson O., 2007. Home sweet home: Social capital and location choice, Social Science. Online: http:// dimetic. dime-eu.org/ dimetic_files/ Lect-to-Sorenson_Dahl-Sorenson.pdf (accessed 11 February 2014).

Dawidko P., 2012. Biotechnologiczne spółki spin-off Uniwersytetu Jagiellońskiego jako mechanizm transferu 
technologii (Jagiellonian University's spin-off companies as a mechanism of technology transfer). Prace Komisji Geografii Przemystu Polskiego Towarzystwa Geograficznego 20: 95-107.

Delerue H., Lejeune A., 2008. Internationalization of biotechnology start-ups: The role of geographical location. Online: http:// uqam.academia.edu/ ALejeune/ Papers/ 456543/ Internationalization_ of_Biotechnology_ Startps_the_Role_of_Geographical_Location (accessed 11 February 2014).

Dohse D., 2000. Technology policy and the regions - the case of the BioRegio contest. Research Policy 29: 1111-1133.

Dohse D., Staehler T., 2008. BioRegio, BioProfile and the rise of the German biotechnology industry. Kiel Working Paper 1456.

Domański B., 2000. Some aspects of the development of Polish manufacturing in the perspective of knowledge-based economy. In: Kukliński A. (ed.), The knowledge-based economy. The European challenges of the 21st century. State Committee for Scientific Research, Warsaw: 281-287.

Dorocki S., Brzegowy P., 2014. France's stand on genetically modified food and its reception in the EU. Rzeszów (in press).

Dorocki S., Jastrzębski J., 2012. Regionalne zróżnicowanie rozwoju biotechnologii w Europie (Regional differences in the development of biotechnology in Europe). Prace Komisji Geografii Przemystu Polskiego Towarzystwa Geograficznego 20: 67-94.

Dorocki S., Borowiec M., Boguś M., 2013. Przestrzenne zróżnicowanie rozwoju przemysłu biotechnologicznego (Spatial differences in the development of the biotechnological industry). Prace Komisji Geografii Przemystu Polskiego Towarzystwa Geograficznego 21, 94-120.

Gałka J., Dorocki S., 2013. Poakcesyjne uwarunkowania rozwoju gospodarki innowacyjnej $\mathrm{w}$ Polsce $\mathrm{w}$ aspekcie migracji klasy kreatywnej (Post-accession determinants of the development of an innovative economy in Poland in terms of migration of the creative class). Prace Komisji Geografii Przemystu Polskiego Towarzystwa Geograficznego 23: 93-105.

Goldberg I., Goddard G., Kuriakose P., 2008. Building knowledge-based economy and absorptive capacity to enhance growth: The role of cross-border knowledge flows in Europe and Central Asia (ECA). In: Runiewicz-Wardyn M., Koźmiński L. (eds), Knowledge-based economy as a factor of competitiveness and economy growth. Academy of Entrepreneurship and Management, Warszawa: 11-24.

Hampel J., Pfenning U., Kohring M., Görke A., Ruhrmann G., 2001. Biotechnology boom and market failure: two sides of the German coin. In: Gaskell G., Bauer M.W. (eds), Biotechnology 1996-2000: The years of controversy. Science Museum, London: 191-203.

Häussler C., Zademach H.-M., 2007. Cluster performance reconsidered: Structure, linkages and paths in the German biotechnology industry, 1996-2003. Schmalenbach Business Review 59(3): 261-281.

Higgins M.J., Rodriguez D., 2006. The outsourcing of R\&D through acquisitions in the pharmaceutical industry. Journal of Financial Economics 80(2): 351-383. DOI: 10.1016/j.jfineco.2005.04.004

Howells J., Gagliardi D., Malik K., 2008. The growth and management of R\&D outsourcing: Evidence from UK pharmaceuticals. RED Management 38: 205-219. DOI: $10.1111 /$ j.1467-9310.2008.00508.
Karlsson Ch., Börje J., 2008. Knowledge, creativity and regional development. CESIS Electronic Working Paper Series 148. Online: http:// www.creativeclass.com/ rfcgdb/ articles/ Entrepreneurship_Creativity_and_Regional_Development.pdf (accessed 11 February 2014).

Kelly M., 2004. Biotechnology clusters in Europe - Biotechnology clusters get a shot in the arm. Online: http:// www. woodsbagot.com/ en/ Documents/ Public_Research/ 04_biocluster_Europe_M_Kelly.pdf (accessed 11 February 2014).

Kilar W., 2008. Zatrudnienie w działalności badawczej i rozwojowej jako czynnik rozwoju gospodarki opartej o wiedzę (Employment in research and development as a factor influencing the growth of knowledge-based economy). Przedsiębiorczość - Edukacja 4: 60-69.

Kilar W., 2009. Zróżnicowanie potencjału ekonomicznego światowych korporacji informatycznych (Diversification of the economic potential of global IT corporations). Prace Komisji Geografii Przemystu Polskiego Towarzystwa Geograficznego 13: 110-121.

Klasik A., 2009. Kreatywne miasta i aglomeracje - studia przypadków (Creative cities and urban agglomerations case studies). Wydawnictwo Akademii Ekonomicznej im. Karola Adamieckiego w Katowicach, Katowice.

Klincewicz K. (ed.), 2012. Klasa kreatywna w Polsce. Technologia, talent i tolerancja jako źródła rozwoju regionalnego (Creative class in Poland. Technology, talent and tolerance as a source of regional development). Wydawnictwo Naukowe Wydziału Zarządzania UW, Warszawa.

Krauss G., Stahlecker T., 2001. New biotechnology firms in Germany: Heidelberg and the BioRegion Rhine-Neckar Triangle. Small Business Economics 17(1-2): 143-153.

Lecocq C., Leten B., Kusters J., van Looy B., 2010. Do firms benefit from being present in multiple technology clusters? An assessment of the technological performance of biopharmaceutical firms. Section of Economic Geography, Papers in Evolutionary Economic Geography 10.19.

Markowski T., 2008. Gospodarka bazująca na wiedzy (GOW) a wyzwania wobec zagospodarowania przestrzennego konceptualizacja problemu (Economy based on knowledge (KBE) and challenges to spatial development - conceptualization of the problem). In: Marszał T. (ed.), Rola polskich aglomeracji wobec wyzwań Strategii Lizbońskiej. Studia KPZK PAN, t. CXX, Warszawa: 35-46.

Marrocu E., Paci R., 2012. Regional development and creativity. Working Papers, Centro Ricerche E Conomiche Nord Sud, Cagliari. Online: http:// crenop.unica.it/ crenos/ sites/default/files/WP12-02.pdf (accessed 11 February 2014).

Müller Ch., 2001. Biotechnology industry in Germany and Japan. Arbeitspapier 11.

Overwalle van G., 2010. Policy levers tailoring patent law to biotechnology. Comparing US and European approaches. Irvine Law Review 1(2): 443-514. Online: http:/ / www. law.uci.edu/lawreview/index.html (accessed 11 February 2014).

Possani D.L., 2003. The past, present, and future of biotechnology in Mexico. Nature Biotechnology 21: 582-583. Online: http:// www.nature.com/ nbt/journal/ v21/ n5/ pdf/ nbt0503-582.pdf (accessed 11 February 2014).

Pugatch M.P., Torstensson D., Chu R., 2012. Taking stock: How global biotechnology benefits from intellectual property rights. Pugatch Consilium, Commissioned by the Biotechnology Industry Organization. Online: http:// www.bio.org/../ 
Pugatch\%20Consilium\%20-\%20Taking\%20Stock\%20Final \%20Report\%20(2).pdf (accessed 11 February 2014).

Rachwał T., 2013. Rola przedsiębiorstw przemysłowych w rozwoju gospodarki opartej na wiedzy (Role of industrial enterprises in the development of a knowledge-based economy). Prace Komisji Geografii Przemystu Polskiego Towarzystwa Geograficznego 21: 189-211.

Rammer Ch., Sellenthin M.O., Fraass B., 2008. Biotechnology in Germany. Monitoring and analysis of policies and public financing instruments conducive to higher levels of RED investments: The "Policy Mix" Project. Centre for European Economic Research. Online: http:// www.academia. edu/ attachments/ 4908907/download_file (accessed 11 February 2014).

Rothaermel F.T., Deeds D.L., 2004. Exploration and exploitation alliances in biotechnology: A system of new product development. Strategic Management Journal 25: 201-221.

Saxenian A., 1999. Silicon Valley's new immigrant entrepreneurs. Public Policy Institute of California, San Francisco.

Saxenian A., Motoyama Y., Quan Xiaohong, 2003. Local and global networks of immigrant professionals in Silicon Valley. Public Policy Institute of California, San Francisco.

Stryjakiewicz T., 2008. Regiony kreatywnej wiedzy - zarys międzynarodowego projektu badawczego ACRE (Regions of creative knowledge - outline of an international research project ACRE). In: Stryjakiewicz T., Czyż T. (eds), O nowy ksztatt badań regionalnych w geografii $i$ gospodarce przestrzennej. Biuletyn KPZK PAN 237, Warszawa: 129-145.

Stryjakiewicz T., 2009. Lokalizacja firm i zachowania przestrzenne pracowników sektora informatycznego (na przykładzie poznańskiego obszaru metropolitalnego) (Location of firms and spatial behaviour of employees of the IT sector (the case of the Poznan metropolitan area)). Prace Komisji Geografii Przemystu Polskiego Towarzystwa Geograficznego 13: 21-33.

Stuart T., Sorenson O., 2003. The geography of opportunity: Spatial heterogeneity in founding rates and the performance of biotechnology firms. Research Policy 32: 229-253.
Sytch M., Bubenzer P., 2008. Research on strategic alliances in biotechnology: An assessment and review. In: Patzelt H., Brenner T. (eds), Handbook of Bioentrepreneurship. Springer, New York: 105-131.

Ukropcova D., Sturdik E., 2009. Biotechnology commercialisation in Europe. Nova Biotechnologica 9(3): 255-264.

Winiarczyk-Raźniak A., Raźniak P., 2012. Migracje wewnętrzne ludności w polskich obszarach metropolitalnych u progu XXI wieku (Internal migration in Polish metropolitan areas on the threshold of the 21st century). Uniwersytet Pedagogiczny Kraków.

Wolf H., Michelsen C., Schwartz M., 2010. Regional entrepreneurial opportunities in the biotechnology industry. Exploring the transition from award-winning ascent entrepreneurs to real start-ups. IWH Discussion Papers 25.

Wójtowicz M., Dorocki S., 2014. Regional differences in the development of the biotechnology industry in Latin America, with particular emphasis on Brazil and Mexico (in press).

Zioło Z., 2003. Model funkcjonowania układu bipolarnego (Model of a bipolar system). In: Zioło Z. (ed.), Bipolarny rozwój aglomeracji: kierunki rozwoju układów bipolarnych. Biuletyn KPZK PAN 209, Warszawa: 29-51.

Zioło Z., 2006. Zróżnicowanie światowej przestrzeni przemysłowej w świetle koncentracji siedzib zarządów wiodących korporacji (Differences in the world industrial space in the light of concentrations of headquarter seats of leading corporations). Prace Komisji Geografii Przemystu Polskiego Towarzystwa Geograficznego 8: 9-26.

Zioło Z., 2008. Procesy transformacji przemysłowych układów przestrzennych na tle zmieniającego się otoczenia (Transformation of industrial spatial patterns in relation to the changing surroundings). Prace Komisji Geografii Przemystu Polskiego Towarzystwa Geograficznego 10: $11-22$.

Zucker L.G., Darby M.R., Armstrong J., 1989. Geographically localized knowledge: Spillovers or markets? Economic Inquiry 36: 65-86. 